\title{
Increasing Company Value Through Financial Policies and Performance of Manufacturing Companies Listed on The Indonesia Stock Exchange
}

\author{
Adhi Widyakto ${ }^{1}$, Endang Tri Widyarti ${ }^{2}$, Edy Suryawardana ${ }^{3}$ \\ ${ }^{1}$ Universitas Semarang, ${ }^{2}$ Universitas Diponegoro, ${ }^{3}$ Universitas Semarang \\ *Correspondence email: edysurya6@usm.ac.id
}

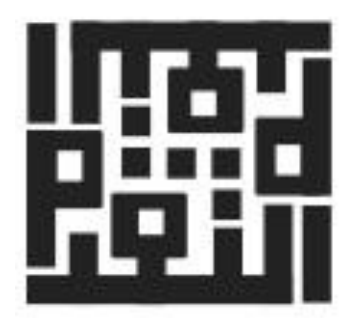

ISSN: 1979-4703 (p)

ISSN: 2527-9726 (e)

\section{Article history:}

Received 7 January 2021

Accepted 27 May 2021

Published 30 June 2021

Keywords:

Capital Structure,

Return, Corporate value, Islamic Perspective, Signal Theory.

\section{A B S T RACT}

The phenomenon that there are still many manufacturing industry companies on the Indonesia Stock Exchange that have a PBV smaller than one is the main basis for conducting the study. This study aims to analyze the effect of financial policy and financial performance on firm value. The sampling technique was based on purposive sampling. The data analysis technique used a linear regression model. Based on the analysis and discussion results, there are four main findings obtained from this study: First, the model used is significant to explain changes in firm value with the ability to explain 48.7 percent. Second, of the five independent variables, there are three variables: the policy in working capital management and the performance variable, namely the volatility of expectations and returns, which have a significant effect. To the value of the company. Third, the company's financial performance factors have a more dominant influence on the company's value dynamics than policy factors. Fourth, the direction coefficient of the influence of the independent variable on the dependent variable, although the two variables are not significant. The practical implication is to increase the value of a manufacturing company. Therefore, it is advisable to consider financial policies and financial performance. Theoretically, financial management based on signal theory and trade-off theory of Islamic perspective theory can increase firm value.

\section{Introduction}

The company's goal is to always be on a sustainable competitive advantage (Sustainable Competitive Advantage) and the company's increasing value (Van Horne, 2005). The high and low value of the company is determined by the company's fundamentals and investors' views, and the company's prospects. The development of stock prices, price earning ratio, or price-book value (PBV) is often used to measure firm value (Ross et al. 1, 2000). Price book value compares 
the value of all shares owned and the company's book value (Brigham, Ehrhardt, 2002). A company is said to be undervalued if it has a value of less than one. (Van Horne, 2005).

The company's value is determined by three main factors: the company's internal factors, external factors, and technical factors. The company's internal and external factors are fundamental factors that are often used to make decisions by investors in the capital market. Meanwhile, technical factors are more technical and psychological, such as stock trading volume, stock trading transaction value, and the tendency of stock prices to rise and fall (Sudiyatno \& Puspitasari, 2010). Meanwhile, according to Syahib (2000), the value of a company is determined by fundamental factors that are very complex and broad in scope, including fundamental macro factors that are outside the company's control and fundamental micro factors that are within the company's control.

This study emphasizes the company's internal factors, which are often seen as important factors to determine the company's value. The company's internal factors in the capital market analysis are often referred to as company fundamental factors. These factors are controllable so that the company can control them. The company's internal factors can be grouped into company policy factors and company performance factors. In this study, the company's policy factors emphasize financial management policies, including capital structure policies, working capital policies, and dividend policies. Meanwhile, the company's performance factor is emphasized on the financial performance aspect (Weston \& Copeland, 1982). However, there are still gaps in the literature.

Dhani \& Utama Studies (2017), Moniaga (2013), Prastuti \& Sudiartha (2016) concluded that capital structure affects firm value. In comparison, the study of Irawan \& Kusuma (2019); Oktaviani (2019) concluded that capital structure does not affect firm value. Budi Setyawan Study (2021), Noor (2017), Haekal Amin (2021) shows that working capital affects firm value. At the same time, studies (Tewuh et al., 2020); (Telaumbanua et al., 2021) show that working capital does not affect firm value. In addition, studies (Sukirni, 2012); (Ayem \& Nugroho, 2016); Indriawati et al. (2018) dividend policy affects firm value, while Kurnia's study (2019); Atmikasari et al. (2020) show that dividend policy does not affect firm value. Likewise, the value of the company is influenced by financial performance. Hasyim \& Adam's Study (2018), Muwidha et al. (2019), Widyawati \& Listiadi (2014) show that financial performance has a positive and significant effect on firm value. While the study by Wardani \& Hermuningsih (2011), Handaru \& Mardiyati (2014), Achmad \& Amanah (2014) show that financial performance does not affect firm value.

Based on the phenomenon in 2017, many companies are going public on the Indonesia Stock Exchange that are in an undervalued position. In that year, of the 159 manufacturing industry companies listed on the BEI, $43 \%$ or 68 companies listed in the industry had a PBV of less than one, with an average PBV of 0.39 (Annual Report, 2017). Although most 
companies (57 percent) have a PBV greater than one, 43 percent of companies with a PBV smaller than one are quite large. Moreover, the average value of the company seen from its PBV is only 0.39. This shows that the value of the company in the view of investors is very bad.

The company's value in the eyes of investors is strongly influenced by his perception of the fundamental factors owned by the company. The key variables of these fundamental factors are mainly related to policies (policies in managing working capital, capital structure (debt), and dividends) as well as variables that reflect the company's performance (ie average and volatility of returns). The average return obtained by a company in a certain period will create a perception for investors or shareholders about the company's expected return (Van Horne, 2025). Signal theory (signaling theory) states the management of working capital, capital structure (policy in managing debt), and foreign exchange

The phenomenon of firm value and the controversy between the theory and the study results above is exciting to study. The study was conducted to analyze the PBV phenomenon and to what extent the company's management policies and company performance reflected in the expected return and volatility affect the firm value. So the problems raised in this study are mainly related to the number of companies in the manufacturing industry in Indonesia that are undervalued or have a market value lower than their book value. The question arises whether the cause of the problem is caused by policies in managing working capital, capital structure, dividends, or expectations and volatility of returns. The purpose of this study was to analyze the effect of working capital policy on firm value, capital structure policy on firm value, the effect of dividend policy on the firm, the effect of expected returns on firm value, and the effect of return volatility on firm value.

\section{Literature Review}

The conceptual framework of this study is based on the concept of Islamic financial management, signal theory, and trade-off theory. The concept of financial management based on Islam reminds that financial management must be carried out carefully, not wastefully. Allah says in the Qur'an, Surah Al Isra, Verses 26 and 27 as follows.

"... and give to close families their rights, to the poor and those who are on the way and do not squander (your wealth) extravagantly"

Whereas in Surah Al Isra Verse 27 Allah says:

"Indeed, the spenders are the brothers of Satan, and the devil is a complete disbeliever in his Lord."

Firman can be interpreted that good financial policies are related to working capital management as measured by the Current Ratio (CR), capital structure as measured by the Debt Equity Ratio (DER), and dividends, as measured by the Dividend, Pay Out Ratio (DPoR). Carefully and not wastefully because it will significantly affect the value of the company. The concept of Islamic financial management parallels Signal Theory and Trade-Off Theory, which also says that working capital management policy, capital structure, and 


\section{At-Taqaddum}

Vol. 13 No. 1 (2021) Pg. 39-56

dividend policy carefully because they will significantly affect firm value (Van Horne, 2005). Adequacy of working capital and high dividend payout ratio (DPoR) will give a positive signal to shareholders/investors to increase the company's value. On the other hand, the high Debt Equity Ratio (DER) signals the company's high financial risk to reduce the company's value (Van Horne, 2005). The trade-off theory says that the larger the DPoR will increase the company's expansion financing dependence on external financing, both from debt and by issuing new shares. Therefore, engage lowering the value of the company.
Based on the company's performance, the signal theory states that the company's average return in a certain period is a signal for the company's expected return. Therefore, the higher the average return (expected return) gives a positive signal about the company's prospects in the future. This condition will increase the company's value. Volatility High return on equity creates a perception in shareholders that the company has a high financial risk. As a result, the desire of investors to invest in the company will decrease or, in other words, will reduce the value of the company. Based on these theories, the propositional pictographic model used in this study can be described as follows.

\section{Figure 1.}

Proposition Pictographic Model

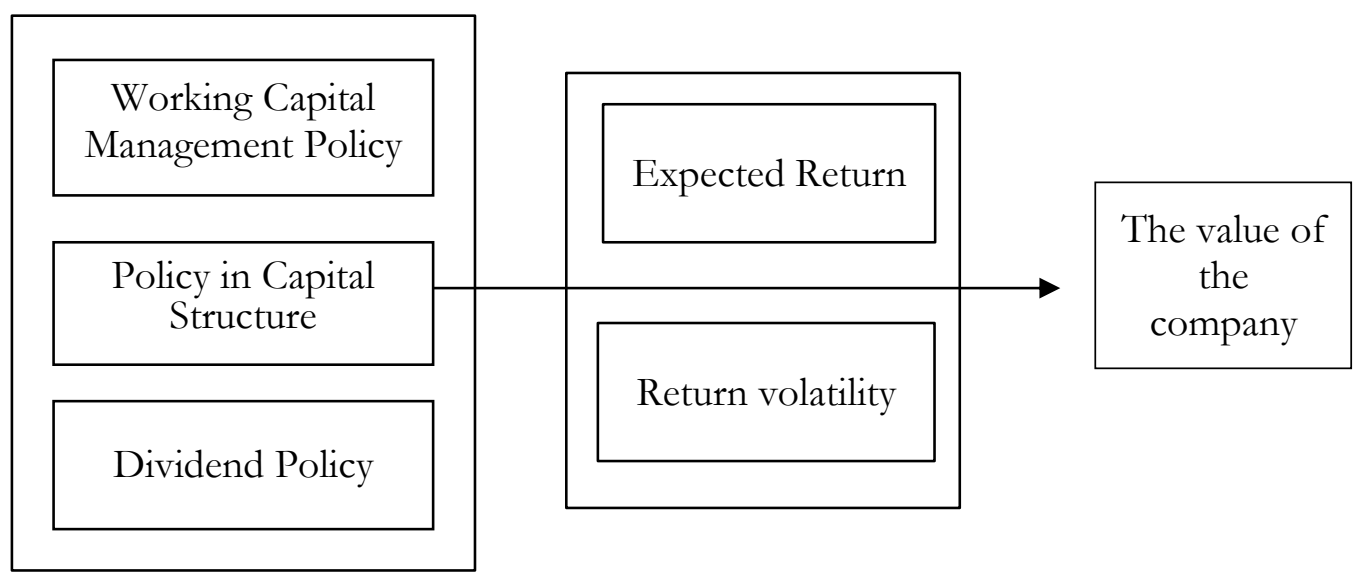

To strengthen researchers in developing a conceptual framework, the description below also describes the views of Islamic economics, signal theory, the trade-off theory, and several studies from previous researchers on causal relationships between variables, both those that reflect policy and performance.

\section{Current Ratio Relationship and Its Effect and Company Value.}

The current ratio shows the company's ability to fulfill obligations, which must be fulfilled immediately (Van Horne, 2009). This variable is a reflection of the company's policy in managing the company's liquidity. Therefore, the high 
current ratio will signal investors about the company's ability to carry out obligations that must be fulfilled immediately and carry out operational activities so that the causal relationship with firm value is parallel (Myers, 2014). But on the other hand, an excessive Current Ratio indicates idle funds in the company (Myers, 2014). As a result, the impact on the company's value is in the opposite direction or negative.

The view that there is no justification for idle in the company follows the concept of Islamic economics. The Qur'an forbids anyone to hoard wealth (Al-Humazah, 104:2-3), even Allah threatens him with a painful punishment (Al-Taubah, 9:34-35, Al-Humazah, 104:4). Based on this concept, it can be said that an excessive Current Ratio will have a negative effect on firm value.

Liquidity in this study uses the Current Ratio (CR) proxy. Current ratio is a ratio used to measure the company's ability to meet its short-term obligations due soon using the total current assets available (Kahfi et al., 2018). A high level of liquidity reduces the company's failure to meet short-term financial obligations to creditors and vice versa. The high or low ratio will affect the interest of investors to invest their funds. If this ratio is getting bigger, the more efficient the company, especially its current assets. This can increase the value of the company which is due to the company's better performance in streamlining the level of liquidity in fulfilling its current liabilities with the ability of its current assets and encouraging the value of the company to increase because of its good performance (Kahfi et al., 2018).
Research Bagh et al. (2016), and Purwanto and Agustin (2017) state that the current ratio positively affects PBV. The results of this study are supported by Hasania et al. (2016); Kahfi et al. (2018); Utami \& Welas (2019) confirmed that the current ratio has a positive and significant effect on PBV. Therefore, the proposed hypothesis is:

H1: current ratio has a positive effect on PBV

\section{Relationship between capital structure and firm value}

Debt in the Islamic perspective is allowed but must be done carefully. Rasulullah SAW said, which means: "Be careful in debt, because debt will bring anxiety at night and humiliation during the day." (HR. Al-Bayhaqi). Based on this perspective, the capital structure policy that leads to a higher proportion of debt represented through DER will reduce firm value. Likewise, signal theory and trade-off theory say that the effect of DER on firm value is significantly negative (Van Horne, 2005).

The debt to equity ratio (DER) measures how far the company uses debt for shortterm and long-term funding. If the risk of paying debts is higher, the possibility of investors investing in a company will decrease and impact providing nonoptimal returns to shareholders. This will get a negative response from investors so that the stock price and company value will decrease. The study results stated that there was a negative effect of the debt to equity ratio on firm value were stated by Azmat and Qurat-ul-ann (2014), Purwanto, and Agustin (2017) Venkatesh, Kavya Ms., at all. 2018 which states that 
the effect of DER on PBV is negative. Therefore, the proposed hypothesis is:

H2: Debt to equity ratio (DER) has a negative effect on PBV

\section{Relationship between Dividend Policy and Company Value.}

The definition of dividend policy in the conventional economic and Islamic perspectives is the same, namely the policy relating to the distribution of profits to shareholders or company owners. The company is formed by two people or more or by a legal entity. These individuals or legal entities perform syirkah or cooperation in the form of capital. From the Islamic perspective, this collaboration is known as syirkah musabamah. syirkah musahamah is business capital participation calculated by the number of shares traded in the capital market. The owners can change easily and quickly. Dividend policy will be reflected in the Dividend Payout Ratio (DPoR). The higher the DPoR will increase shareholders' welfare. A high Dpor will also give a positive signal to shareholders or investors that the company has been managed properly, thus increasing the company's value. So based on the theory based on the Islamic perspective and signal theory, the effect of DPoR on firm value is a significant positive. Both of these theories are supported by Suwarno, at all (2016) in his study found that the Dividend Payout Ratio has a significant positive effect on firm value. The results of this study are also supported by the Septarian study (2017); Sulistiono, (2016); Suwaldiman \& Ramadhan (2019); Meilina \& Tjong (2019). Therefore, the proposed hypothesis is:
H3: Dividend Payout Ratio has a positive effect on PBV

\section{Relationship of Expected Return (ER) and firm value}

The average return on equity (ROE) in a period signals to shareholders and investors about the expected return that the company will obtain. The higher the average return, the higher the expected return from shareholders and investors. The impact will certainly increase the value of the company. This is in line with the study conducted by Purwanto, $\mathrm{P}$ and Jillian Agustin, Jillian (2017), which found that expected return has a positive effect on firm value. Therefore, the proposed hypothesis is:

H4: expected return has a positive effect on PBV

\section{Relationship between return volatility and firm value}

Volatility is the distance between rising and falling stock prices. The high return volatility is a signal of the uncertainty of the return obtained by the company. This phenomenon reflects the high business risk or financial risk of the company. This signal will certainly reduce the value of the company. Volatility is an operational risk, so the higher the fluctuation, the higher the risk that the company will face in the future. This is in line with the results of research by Fanani (2010), which revealed that sharp fluctuations in cash flows would result in company profits which are increasingly difficult to predict, which means that the greater the volatility of cash flows, the lower the level of company profits. A decrease in net income will result in a decrease in earnings per share and will eventually 
decrease stock prices and decrease the company's value (Noerirawan, 2012; Sartika et al., 2019; Sofyaningsih, 2011). Therefore, the proposed hypothesis is:
H5: Return volatility has a negative effect on PBV

Based on the literature review, the conceptual framework that will be used in this study can be described in Figure 2 .

\section{Figure 2.}

\section{Conceptual Framework.}

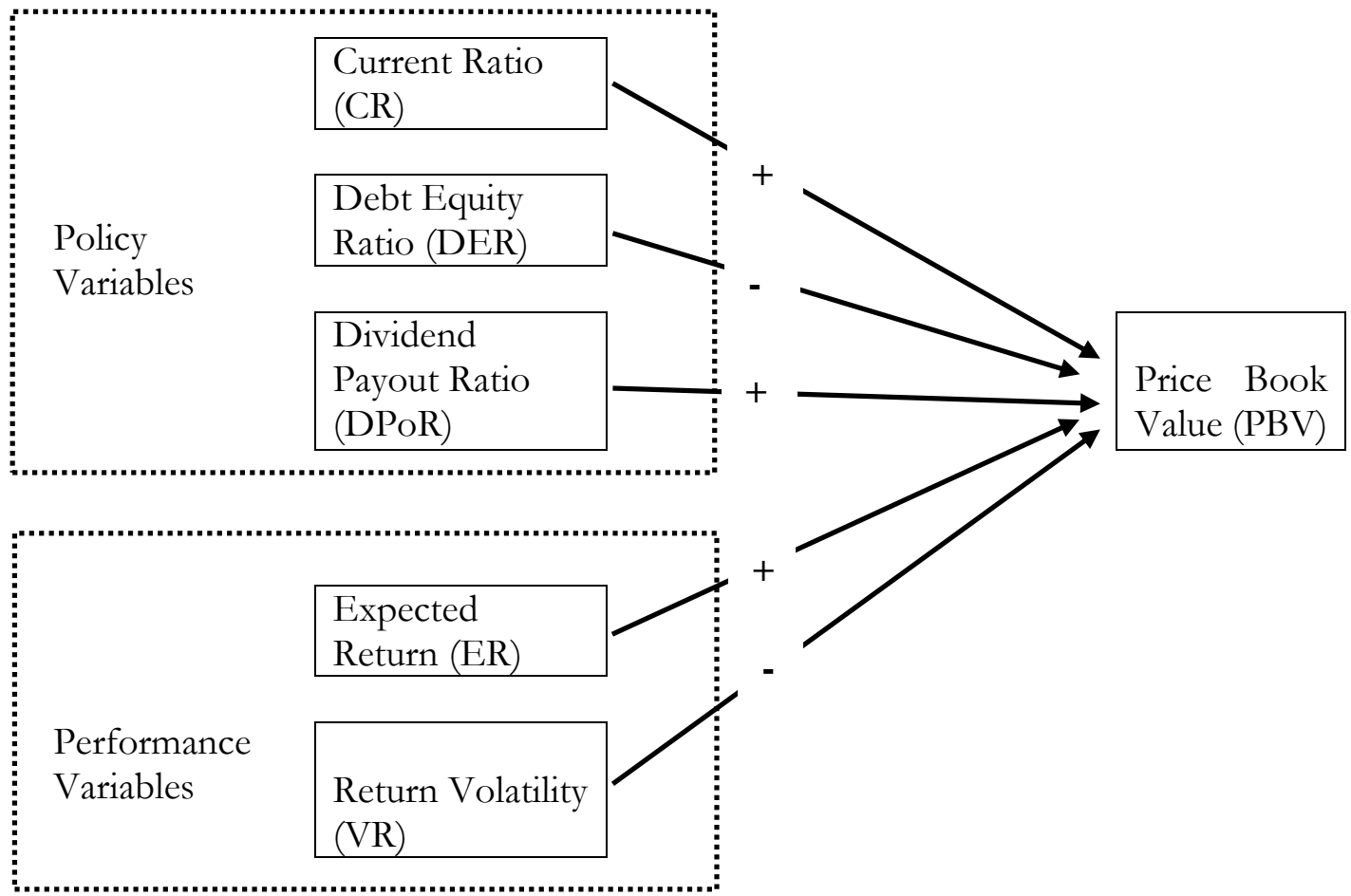

\section{Research Method}

The data used in this study is secondary data from manufacturing industry companies listed on the Indonesia Stock Exchange in 2014, 2015, 2016, and 2017. In 2014-2017 many companies that went public on the Indonesia Stock Exchange were undervalued. The choice of manufacturing industry companies is the object of research because the number of companies listed on the Indonesia Stock
Exchange is the largest compared to other industries.

The total population of companies in the industry is 80 , while the sample used in this study is 48 . Sampling using purposive sampling was carried out on the availability of data for the variables studied for four years, starting in 2014, 2015, 2016 and 2017. The data used is Price Book Value data which reflects the value of the company. Current Ratio which reflects policies in working capital 


\section{At-Taqaddum}

Vol. 13 No. 1 (2021) Pg. 39-56

management, Debt Equity Ratio, Dividend Payout Ratio, Average Return Equity from 2014 to 2017 which reflects expected returns, and volatility of return on equity during 2014 to 2017 .

The analytical technique used to answer the research objectives is using the multiple regression model used for analysis, which can be seen in equation (1) below:

\section{$\mathrm{PBV}=0+1 \mathrm{CR}+2 \mathrm{DER}+3 \mathrm{DPoR}+$ $4 \mathrm{ER}+4 \mathrm{VR}+(1)$}

description:

PBV: Ratio that compares the stock price with the book value of the company

CR: Current ratio (comparison between current assets and shortterm debt)

DER: Ratio of debt compared to equity DPoR: Dividend Payout Ratio (comparison between dividends and company income after tax.

ER: Expected return which is calculated based on the average return for four years (2014 to 2017)

The model's findings will be tested using the $F$ test to determine whether the model used in this study can significantly explain changes in the dependent variable. The model will also be seen to what extent it can explain changes in the intervening and dependent variables by using the coefficient of determination (R2 adjusted). After that, it will be tested whether the effect of each independent variable on the intermediate and dependent variables is significant or not.

The test results show whether policies in the management of working capital, capital structure, dividend policy, expected returns, and return volatility significantly affect firm value, as measured by PBV. The test results can also be seen whether policy variables or performance variables more influence the firm value. Before being used for prediction, the equation results from the model will be tested first whether it meets the BLUE (Best Linear Unbiased Estimate) requirements. The results meet the normality requirements and do not contain multicollinearity, heteroscedasticity, and autocorrelation.

\section{Result and Discussion}

This section consists of two parts: the first is a descriptive analysis which provides an overview of the variables used in this study. Second, regression analysis based on the model.

\section{PBV $=0+1 \mathrm{CR}+2 \mathrm{DER}+3 \mathrm{DPoR}+$ $4 \mathrm{ER}+4 \mathrm{VR}+$}

\section{Descriptive Analysis}

An overview of the variables studied in this study can be seen in Table 1 below. 


\section{Table 1.}

$V$ ariable descriptive statistics

\begin{tabular}{lrrr}
\hline & \multicolumn{1}{c}{ Mean } & Std. Deviation & $\mathrm{N}$ \\
\hline PBV & 2.523 & 4.457 & 48 \\
AVG CR (\%) & 301.339 & 270.823 & 48 \\
AVG DPoR (\%) & 46.034 & 61.861 & 48 \\
AVG DER & .923 & .857 & 48 \\
AVG ROE (\%) & 10.837 & 8.569 & 48 \\
VOLATILITAS & & 11.021 & 48 \\
RETURN (\%) & -3.008 & & \\
\hline
\end{tabular}

In Table 1 it can be seen that of all the companies studied, for four years (2014 to 2017) they had an average PBV of 2,523 with a standard deviation of 4,457 . This is an indication that the shareholder or investor's assessment of these companies is quite good. However, judging by the standard deviation of the PBV, which is greater than the average, it shows that the value disparity between companies in the industry is high (Purbawangsa, At All. 2020). From 2014 to 2017, the manufacturing industry company had a very high current ratio of around 301.339 percent and a standard deviation of 270,823 . On the one hand, this phenomenon shows that the working capital of these companies can fulfill obligations that must be fulfilled immediately. Still, on the other hand, it shows the occurrence of idle funds in the company. Van Horne (2009) states that the ideal Current Ratio is 2:1.

On average, these companies pay dividends of 46.034 percent of profit after tax. However, the policy variation in the dividend payout ratio is high, which is indicated by the higher DPoR standard deviation to the average.

The average manufacturing industry company has a DER of 0.923 with a standard deviation of 0.857 , which is smaller than the average. The smaller standard deviation compared to the average indicates that in the capital structure policy, the behavior of the company's management is relatively more homogeneous.

The average ROE that reflects these companies' Expected Return on Equity is 10.837 percent, with a standard deviation of 8.569 (smaller than the average). This shows the gap in the ability of companies in the manufacturing industry to generate a relatively small return on equity. The average return volatility is -3.008 with a standard deviation of 11.021 (greater than the average). Therefore, the coefficient of average return volatility, which has a negative sign, indicates that in the period 2014 to 2017, the average return of these companies tends to decrease, with the 


\section{At-Taqaddum}

Vol. 13 No. 1 (2021) Pg. 39-56

level of decline for each different company being quite large, because the standard deviation of the return is larger. Compared to the average.

\section{Regression Analysis}

The results of the regression equation using equation (1) can be seen in Table 2 below.

\section{Table 2}

Result of Equation

$\mathrm{PBV}=\alpha_{0}+\alpha_{1} \mathrm{CR}+\alpha_{2} \mathrm{DER}+\alpha_{3} \mathrm{DPoR}+\alpha_{4} \mathrm{ER}+\alpha_{4} \mathrm{VR}+\varepsilon$

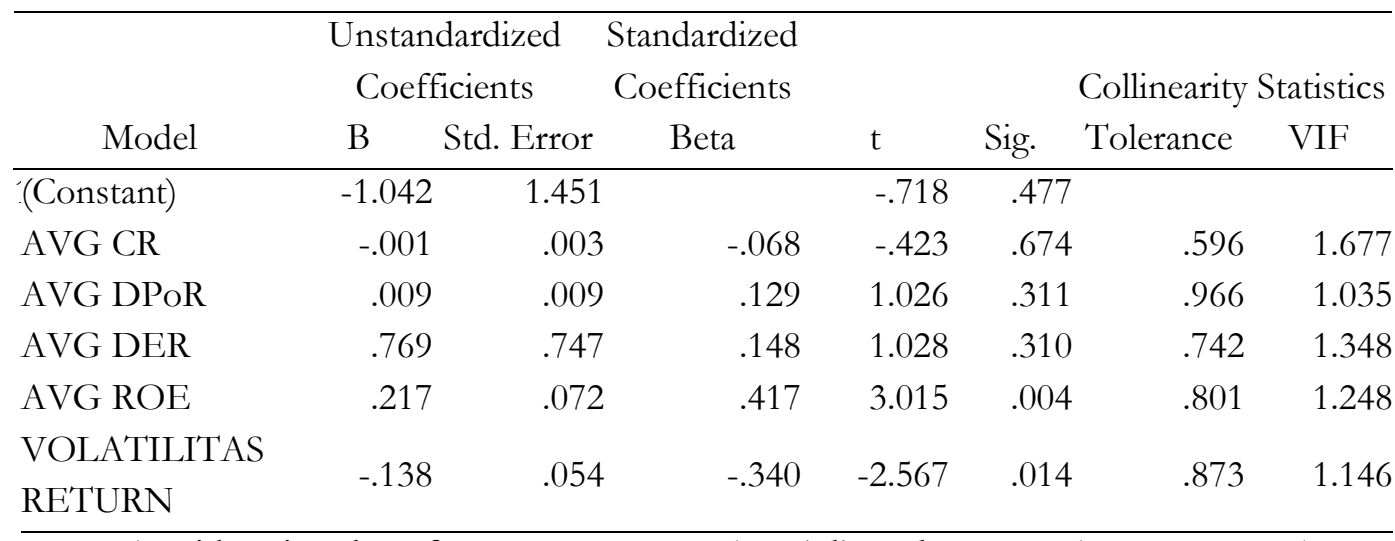

$\mathrm{F}=4.653$ with a sig value of $\mathrm{F}=0.002 ; \mathrm{R} 2=0.597$; Adjusted $\mathrm{R} 2=0.356 ; \mathrm{DW}=1.325$

The regression equation results in Table 2 do not meet the BLUE assumption because, first, it does not meet the normality assumption and contains heteroscedasticity. Heteroscedasticity occurs between the residual value and PBV. To eliminate heteroscedasticity by transforming the PBV variable into Ln
PBV (Gujarati, 2009). The new equation resulting from the transformation can be seen in equation two below.

\section{Ln PBV = 0+ $1 \mathrm{CR}+2 \mathrm{DER}+3 \mathrm{DPoR}$$$
+4 \mathrm{ER}+4 \mathrm{VR}+(2)
$$

The regression results from Equation (2) can be seen in Table 3 as follows.

\section{Table 3}

Equation Result Equation

$\mathrm{Ln} \mathrm{PBV}=\beta_{0}+\beta_{1} \mathrm{CR}+\beta_{2} \mathrm{DER}+\beta_{3} \mathrm{DPoR}+\beta_{4} \mathrm{ER}+\beta_{4} \mathrm{VR}+\mu$

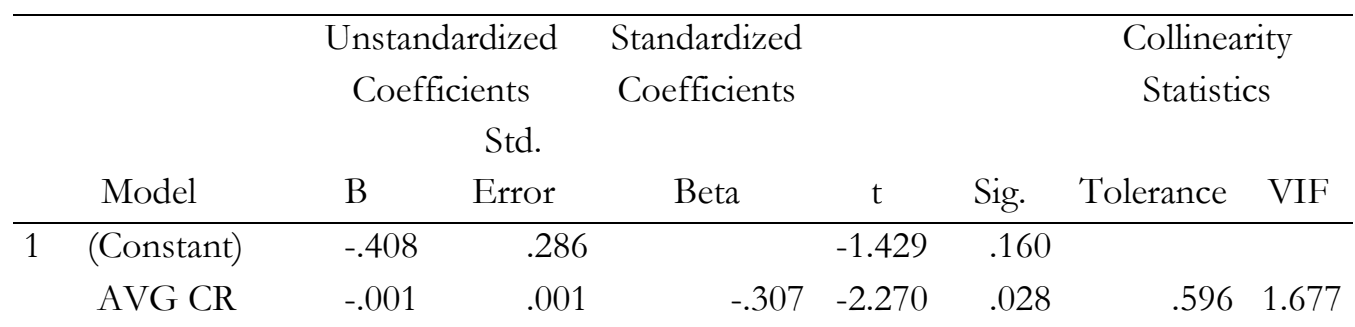




\begin{tabular}{|c|c|c|c|c|c|c|c|}
\hline AVG DER & -.065 & .147 & -.054 & -.442 & .661 & .742 & 1.348 \\
\hline $\begin{array}{l}\text { AVG } \\
\text { DPoR }\end{array}$ & .002 & .002 & .093 & .877 & .386 & .966 & 1.035 \\
\hline AVG ROE & .089 & .014 & .730 & 6.253 & .000 & .801 & 1.248 \\
\hline $\begin{array}{l}\text { VOLATI- } \\
\text { LITAS } \\
\text { RETURN }\end{array}$ & -.019 & .011 & -.203 & -1.814 & .077 & .873 & 1.146 \\
\hline
\end{tabular}

Regression equation 2 shows that the normality, multicoloniarty, heteroscedasticity, and autocorrelation tests have met the requirements. The results meet the normality requirements, do not contain multicollinearity, which is indicated by the correlation between the independent variables having a tolerance greater than 0.1 and a VIF less than 10 (see Table 3). The regression equation also does not contain heteroscedasticity and autocorrelation.

Based on Table 3, it can be said that the model is significant enough to explain changes in PBV. The F value of the model is $=9.928$ with a significance of $\mathrm{F}$ of $=$ 0.000 . Therefore, the ability of the model to explain the dynamics of PBV is 0.487 or 48.7 percent, which means that the equation 2 models cannot explain 51.3 percent of changes in PBV. These variables are assumed to be macroeconomic variables such as inflation, changes in currency values, political dynamics, etc. Macro variables were not examined in this study because the data used in the regression analysis was cross-sectional data (average and return volatility for four years). Therefore, research using macro variables must use time-series data.

Based on the partial analysis (see Table 3), it turns out that when used using a significance level of $5 \%$, only the expected return variable has a significant effect on PBV. Still, if a significance level of $10 \%$ is used, three variables significantly influence PBV, namely: Current Ratio, expected return, and return volatility. Therefore, the hypothesis test of the effect of the independent variable on the dependent variable is as follows (see Table 3).

1) The effect of the Current Ratio on PBV with a negative directional coefficient, meaning that it is not following the working hypothesis formulated in this study, which is significantly positive. So even though the results are significant at a significance level of 5 percent one-tail test, the coefficients are different in direction. The findings of the current ratio have a causal relationship with the coefficient of the negative direction, indicating that idle funds have occurred in these companies. Following the Islamic view and signal theory, excessive idle funds will reduce the company's value. This finding is also consistent with studies conducted by Macit, Fatih, and Topaloglu (2012) and Pouraghajan and Emaggholipourarchi (2012).

2) The effect of DER on PBV is not significant either by using a significance level of 5 percent or $10 \%$ one tail test (the working hypothesis of this study is 
rejected). However, the direction coefficient of the findings is by the working hypothesis that has been formulated, which is negative. Furthermore, this insignificant finding is under the findings of Tahir et al. (2011).

3) The effect of DPoR on PBV is not significant either at the 5 percent or 10 percent significance level. However, the finding direction coefficient follows the working hypothesis, which is positive. This finding follows the findings of Suhadak et al. (2018) stated that the effect of DPoR on firm value was not significant.

4) The effect of expected return on PBV is significantly positive, either by using a significance level of 5 percent or 10 percent. This finding follows the working hypothesis formulated in this study, so the working hypothesis of this research is accepted.

5) The effect of return volatility on PBV is significantly negative at a significance level of 10 one-sided tests. This means that it follows the working hypothesis formulated in this study, so the working hypothesis of this research is accepted.

Table 3 shows that seen from the standardized coefficient, it turns out that the expected return, which is proxied through the average return obtained by the company during 2014 to 2017, has the most dominant influence on the value of the company, which is 0.730 , then followed by return volatility (with a direction coefficient of 0.730). negative) and the new working capital management policy with (negative direction coefficient). The results of this study indicate that the attention of shareholders/investors to the company's performance represented by expected return and return volatility is more dominant than the influence of company management policy variables in the management of working capital, capital structure, and dividends. Even the capital structure and dividend policies do not have a significant impact on firm value.

Policies in the management of working capital have a negative directional coefficient with changes in firm value. This finding can be interpreted that the amount of working capital embedded in the company is at a level that indicates the number of idle funds embedded in the company. This is also based on descriptive findings where the average current ratio of the companies studied is 301.339 percent or 3.01339 to 1 , whereas ideally it is $2: 1$ (Van Horne, 2005).

\section{Conclusion}

There are six conclusions that can be written in this study, namely as follows, Management policy in managing working capital turns out to have a negative causal relationship with firm value, this happens because the company's current ratio is already above the ideal current ratio of 2:1 (See Table 1) giving the impression that the increase in the current ratio is parallel with the increase in the company's idle funds and this will reduce the value of the company. Policies in the capital structure have no significant effect on firm value. This means that investors/shareholders have not paid attention to the policy. Conditions are possible when the company's debt is still considered safe by shareholders/investors because the Debt Equity Ratio is still below 1. The effect of dividend policy on PBV is also insignificant. This indicates that the 
attention of shareholders/investors on this policy has not been maximized. This condition is possible if the company's policy in paying dividends is adequate. The company's expected return during 2014 to 2017 has a significant influence on the company's value. An increase in Expected Return of one percent will increase the value of the company by 0.89 percent. Judging from the comparison with other variables, the effect of expected return on firm value is the greatest. This finding is following the phenomenon that occurs in the behavior of stock prices, that the expected return, in general, is the main concern of investors. Return volatility has a significant effect on firm value. An increase in return volatility by one will reduce the value of the company by 1.9 percent. This finding is also in line with the phenomenon that occurs that the volatility of the company's return is a major concern for investors/shareholders. The findings also show that the company's performance variables are fundamental variables that play an important role in increasing company value compared to policy variables. The findings also show that the direction coefficient of the influence of all the independent variables studied (both policy and performance variables) on the dependent variable (firm value) follows the Islamic view of financial management and under signal theory and trade-off theory. However, there are two of the five variables studied were not significant. This means that Islamic economic theories regarding financial management are very relevant to be implemented in policies for managing working capital, capital structure and dividends.

\section{Recommendation}

Three recommendations can be conveyed in this study, namely as follows. First, the findings showing that expected return and return volatility are dominant variables in determining firm value have implications for management always to increase the firm's expected return and maintain the stability of its return. Second, increasing the company's internal efficiency in managing working capital (to avoid idle capital and efficiency in managing capital structure) must be a management commitment to increase returns. Third, efforts to direct working capital towards an ideal direction to reduce idle funds are strategic efforts to convince shareholders/investors that there will be no waste of funds used due to a large number of idle funds. This effort is in line with Islamic philosophy in financial management. Finally, suggestions for future research are similar studies but using time series data to detect the effect of macro variables such as inflation rates, changes in currency values and political dynamics in the research model. Including these variables is expected to increase the model's ability to analyze the dynamics of firm value.

\section{References}

Achmad, S. L., \& Amanah, L. (2014). Pengaruh Keputusan Investasi, Keputusan Pendanaan, Kebijakan Dividen dan Kinerja Keuangan Terhadap Nilai Perusahaan. Jurnal Ilmu \& Riset Akuntansi, 3(9), 1-15.

Atmikasari, D., Indarti, I., \& Aditya, E. M. (2020). Pengaruh Profitabilitas terhadap Nilai Perusahaan dengan 


\section{At-Taqaddum}

Vol. 13 No. 1 (2021) Pg. 39-56

Kebijakan Deviden sebagai Variabel Intervening. Jurnal Ilmiah Aset, 4(1), 25-34.

https://doi.org/10.52624/cash.v4i02 .1802

Ayem, S., \& Nugroho, R. (2016). Pengaruh Profitabilitas, Struktur Modal, Kebijakan Deviden, dan Keputusan Investasi Terhadap Nilai Perusahaan (Studi Kasus Perusahaan Manufaktur Yang Go Publik di Bursa Efek Indonesia) PERIODE 2010 - 2014. Jurnal Akuntansi, 4(1), 31-39. https://doi.org/10.24964/ja.v4i1.12 5

Azmat, Qurat-ul-ann. 2014. "Firm Value and Optimal Cash Level: Evidence from Pakistan". International Journal of Emerging Markets. Vol. 9 No. 4, 2014

Bagh, et all (2016). "The Impact of Working Capital Management on Firms Financial Performance: Evidence from Pakistan". International Journal of Economics and Financial Issues, 6(3), 1097-1105

Budi Setyawan. (2021). Pengaruh Modal Kerja Dan Profitabilitas Terhadap Nilai Perusahaan. Jurnal Bisnis Terapan, 5(1), 73-88. https://doi.org/10.24123/jbt.v5i1.40 93

Dhani, I. P., \& Utama, A. . G. S. (2017). Pengaruh Pertumbuhan Perusahaan, Struktur Modal, Dan Profitabilitas Terhadap Nilai Perusahaan. Jurnal Riset Akuntansi Dan Bisnis Airlangga, 2(1), 135-148. https://doi.org/10.31093/jraba.v2i1. 28

Fanani, Z. (2010). Analisis Faktor-Faktor
Penentu Persistensi Laba. Jurnal Akuntansi Dan Keuangan Indonesia, 7(1), 109-123.

https://doi.org/10.21002/jaki.2010. 06

Gozali, Imam. 2014. Ekonometrika, Teori, Konsep dan Aplikasi dengan IBM SPSS 22. Badan Penerbit Universitas Diponegoro, Semarang.

Gujarati, Damodar N., Porter, Dawn 2009. Basic Econometrics. McGraw Hill International Edition, New York.

Haekal Amin, J. (2021). Pengarub Modal Kerja Bersib, Arus Kas Operasi Dan. 6(1), 92-107.

Handaru, A., \& Mardiyati, U. (2014). Jurnal Dinamika Manajemen. Jdm, 5(2), 171182.

Hasania, Z., Murni, S., \& Mandagie, Y. (2016). Pengaruh Current Ratio, Ukuran Perusahaan Struktur Modal, Dan Roe Terhadap Nilai Perusahaan Farmasi Yang Terdaftar Di Bursa Efek Indonesia Periode 2011 - 2014. Jurnal Berkala Ilmiah Efisiensi, 16(3), 133-144.

Hasyim, M. A. N., \& Adam, A. (2018). Pengaruh Kinerja Keuangan Internal Perusahaan Terhadap Nilai Perusahaan. Jurnal Ilmiah Akuntansi Dan Keuangan, 1(1), 96-123.

Indriawati, I., Ariesta, M., \& Santoso, E. B. (2018). Pengaruh profitabilitas, keputusan Investasi, pertumbuhan perusahaan terhadap nilai perusahaan dengan kebijakan deviden sebagai variabel intervening pada perusahaan manufaktur food and beverage yang terdaftar di Bursa Efek Indonesia tahun 2012 -2016. Journal of Accounting, 
1-19.

Irawan, D., \& Kusuma, N. (2019). Pengaruh Struktur Modal Dan Ukuran Perusahaan Terhadap Nilai Perusahaan. Jurnal AKTUAL, 17(1), 66.

https://doi.org/10.47232/aktual.v17 i1.34

Kahfi, M. F., Pratomo, D., \& Aminah, W. (2018). Pengaruh Current Ratio, Debt to Equity Ratio, Total Assets Turn Over dan return On Equity Terhadap Nilai Perusahaan ( Studi Kasus Pada Perusahaan Manufaktur Sektor Food and Beverage Yang Terdaftar Di Bursa Efek Indonesia Pada Tahun 2011 - 2016 ). E-Proceeding of Management, 5(1), 566-574. https://openlibrarypublications.telko muniversity.ac.id/index.php/manage ment/article/view/6264/6243

Kurnia, D. (2019). Profitabilitas, Kebijakan Dividen dan Harga Saham Terhadap Nilai. Jurnal Akuntans, 6(2), 178-187.

Macit, Fatih, and Topaloglu. 2012. "Why Bank Market Value to Book Value Ratios so Different: Evidence from Turkish Banking Sector". Economic and Business Review, Vol 14, No 2. 2012.

Meilina, \& Tjong, W. (2019). Pengaruh Likuiditas, Profitabilitas, Dividend Payout Ratio dan Ukuran Perusahaan Terhadap Nilai Perusahaan Pada Industri Rumah Sakit Yang Terdaftar Di Bursa Efek Indonesia Periode 2015 - 2019. Jurnal EMB A, 9(1), 807823.

Moniaga, F. (2013). Struktur Modal, Profitabilitas dan Struktur Biaya Terhadap Nilai Perusahaan Industri
Keramik, Porcelen dan Kaca Periode 2007 - 2011. Jurnal EMBA, 1(4), 433442.

Muwidha, M., Himma, M., \& Riwajanti, R. (2019). Analisis Pengaruh Kinerja Keuangan Terhadap Nilai Perusahaan Dengan Kebijakan Dividen Dan Earning Per Share Sebagai Variabel Pemoderasi Pada Perusahaan Yang Tergabung Dalam Jakarta Islamic Index (Jii). Adbis: Jurnal Administrasi Dan Bisnis, 12(2), 148. https://doi.org/10.33795/jadbis.v12i2.53

Myers, Brealey. 2014. Princples of Corporate Finance. McGraw-Hill Education (Asia), Singapore

Noerirawan, M. R. (2012). Pengaruh Faktor Internal dan Timeliness Laporan Keuangan. Universitas Diponegoro.

Noor, M. Y. (2017). Analisis Pengaruh Struktur Modal dan Perputaran Modal Kerja Terhadap Nilai Perusahaan Pada Perusahaan Manufaktur Yang Tercatat Pada Bursa Efek Indonesia. Akmen Jurnal Ilmiah, 14(2), 354-368.

Oktaviani, M. (2019). Pengaruh Ukuran Perusahaan (Size) dan Struktur Modal Terhadap Nilai Perusahaan. Balance Vol. XVINo. 1

Prastuti, N. K. R., \& Sudiartha, I. G. M. (2016). Pengaruh Struktur Modal, Kebijakan Dividen, dan Ukuran Perusahaan Terhadap Nilai Perusahaan Pada Perusahaan Manufaktur. E-Jurnal Manajemen Unud, 5(3), 1572-1598.

Pouraghajan, Abbasali and Emamgholipourarchi, Milad. 2012. 
"Impact of Working Capital Management on Profitability and Market Evaluation: Evidence from Tehran Stock Exchange". International Journal of Business and Social Science. Vol. 3 No. 10 [Special Issue - May 2012]

Purwanto, P dan Jillian Agustin, Jillian (2017). "Financial Performance towards Value of Firms in Basic and Chemicals Industry", European Research Studies Journal, Volume XX, Issue 2A, 2017

Purbawangsa, At All. 2020. "Corporate Governance, Corporate Profitability Toward Corporate Social Responsibility Disclosure and Corporate Value (Comparative Study in Indonesia-China And India Stock Exchange in 2013-2016)". Social Responsibility Journal. Emerald Publishing Limited.

Sartika, U. D., Siddik, S., \& Choiriyah. (2019). Pengaruh Inflasi, Suku Bunga, Nilai Tukar, Dan Produk Domestik Bruto Terhadap Nilai Perusahaan. Jurnal Ilmu Manajemen, 8(2), 75. https://doi.org/10.32502/jimn.v8i2. 1821

Septarian, D. (2017). Pengaruh Kebijakan Dividen dan Kebijakan Hutang Terhadap Nilai Perusahaan (Studi Empiris Pada Perusahaan LQ45 di BEI Periode 2012-2015). Journal of Applied Business and Economics, 3(3), 183-195.

https://gain.fas.usda.gov/Recent GAIN Publications/Agricultural Biotechnology

Annual_Ottawa_Canada_11-202018.pdf\%0Ahttps://doi.org/10.101 6/j.resourpol.2020.101869\%0Ahttp: //dx.doi.org/10.1016/j.jenvman.201

7.06.039\%0Ahttp://www.oecd.org/ gov/regulatory-poli

Sofyaningsih, S. (2011). Struktur Kepemilikan, Kebijakan Dividen, Kebijakan Utang dan Nilai Perusahaan Ownership Structure, Dividend Policy and Debt Policy And Firm Value. Dinamika Kenangan Dan Perbankan, 3(1), 68-87.

Sudiyatno, B., \& Puspitasari, E. (2010). Pengaruh Kebijakan Perusahaan Terhadap Nilai Perusahaan Dengan Kinerja Perusahaan Sebagai Variabel Intervening (Studi pada Perusahaan Manufaktur di Bursa Efek Indonesia). Dinamika Keuangan Dan Perbankan, 2(1), 1-11.

Suhadak, at all. 2018. "GCG, financial architecture on stock return, financial performance and corporate value". International Journal of Productivity and Performance Management (C) Emerald Publishing Limited 1741-0401 DOI 10.1108/IJPPM-09-2017-0224.

Sukirni, D. (2012). Kepemilikan Manajerial, Kepemilikan Institusional, Kebijakan Deviden dan Kebijakan Hutang Analisis Terhadap Nilai Perusahaan. Accounting Analysis Journal, 1(2), 1-12.

Sulistiono, S. (2016). Pengaruh Struktur Modal , Kebijakan Dividen dan Investment Opportunity Set terhadap Nilai Perusahaan ( Studi pada Perusahaan-perusahaan Manufaktur di PT . Bursa Efek Indonesia ). Industrial Research, Workshop, and National Seminar, 26-34. 
Suwaldiman, S., \& Ramadhan, J. (2019). Asset Instrumen Keuangan Dan Free Cash Flow Terhadap Nilai Perusahaan: Dividend Payout Ratio Sebagai Pemoderasi. Jurnal Bisnis Dan Akuntansi, 21(1), 27-38. https://doi.org/10.34208/jba.v21i1. 423

Syahib, N. (2000). Analisis Pengaruh Beberapa Faktor Fundamental Dan Risiko Sistematik Terhadap Harga Saham Kasus Industri Barang Konsumsi Yang Go-Publik di Pasar Modal Indonesia. Journal of Indonesian Economy and Business, 15(3), 294-312.

Tahir, Iza Mohd and Razali, Ahmad Rizal. 2011. "The Relationship between Enterpise Risk Management (ERM) and Firm Value: Evidence From Malaysian Public Listedd Companies".International Journal of Economics and Management Sciences. Vol 1, No. 2. 2011

Telaumbanua, H., Simanjuntak, V. A., Marbun, M., Sembiring, E. A. B., \& Aruan, D. A. (2021). Pengaruh Struktur Modal, Perputaran Modal Kerja, Kebijakan Dividen Terhadap Nilai Perusahaan Dengan Profitabilitas Sebagai Variabel Moderatig Pada Perusahaan Infrastruktur Yang Terdaftar Dibursa Efek Indonesia Periode 2015-2018. KRISNA: Kumpulan Riset Akuntansi, 12(2), 266-277. https://doi.org/10.22225/kr.12.2.24 85.266-277

Tewuh, N. E., Murni, S., Maramis, J. B., Perusahaan, P., Tidak, Y., Dividen, M., \& Industri, D. I. (2020). Sub Sektor Logam Dan Lainnya Yang Terdaftar Di Bei) Factors Affecting the Value of the
Company ( in Companies That Do Not Share Dividends in the Metal and Other Sub Sector Manufacturing Industries Listed on the $I d x) .8(1), 212-221$.

Utami, P., \& Welas. (2019). Pengaruh Current Ratio, Return On Asset, Total Asset Turnover dan Debt To Equity Ratio Terhadap Nilai Perusahaan (Studi Empiris pada Perusahaan Manufaktur Sub Sektor Properti dan Real Estate Yang Terdaftar di Bursa Efek Indonesia Periode 2015-2017). Jurnal Akuntansi Dan Keuangan, 8(1), 57-76.

Van Horne, James C. 2005. Financial Management and Policy. Prentice Hall International Corporation. New Jersey.

Venktesh, Kavya Ms., at all. 2018. "A Study on Risk and Return Analysis and Data Envelopment Analisys of Publik and Private Sector Banks". Srusti Management Review, Vol XII, issue II, July-December 2018

Wardani, D. K., \& Hermuningsih, S. (2011). Pengaruh Struktur Kepemilikan terhadap Nilai Perusahaan dengan Kinerja Keuangan dan Kebijakan Hutang sebagai Variabel Intervening. Jurnal Siasat Bisnis, 15(1), 27-36. https://doi.org/10.20885/jsb.vol15.i ss1.art3

Weston, J. F., \& Copeland, T. E. (1982). Managerial finance. Fort Worth: Dryden Press.

Widyawati, N. T., \& Listiadi, A. (2014). Pengaruh Kinerja Keuangan Terhadap Nilai Perusahaan Dengan Pengungkapan Corporate Social Responsibility Sebagai Variabel 


\section{At-Taqaddum}

Vol. 13 No. 1 (2021) Pg. 39-56

Moderasi. Jurnal Ilmu Manajemen, 2(4), 1394-1404. 